\title{
Analyzing Grammatical Error in Students' Recount Text Writing in Junior High School
}

\author{
Ni Putu Ines Marylena Candra Manik ${ }^{*}$, Ni Komang Arie Suwastini \\ Universitas Pendidikan Ganesha \\ Email: inesmarylena@gmail.com \\ Denpasar, Bali, Indonesia \\ *Corresponding Author
}

\begin{abstract}
Having good grammar is one of important components in the mastery of writing skills. However, grammatical errors still become an important problem in writing, especially for EFL students. Therefore, this study aimed to find out the major types of grammatical errors; and to know the major source of grammatical errors in students' recount text writing. This study was designed as a descriptive qualitative study. Recount texts written by the eighth-grade students of SMP Pelangi Dharma Nusantara in academic year 2019/2020 were used as the research subjects of this study. The data were identified and analyzed using theory of error proposed by Dulay et al. (1982) about surface strategy taxonomy and theory of source of grammatical error proposed by Brown (2007)). The findings showed that the major type of grammatical errors was omission, with the total of 171 errors or $37.33 \%$ of the total errors. Meanwhile, the major source of grammatical errors was intralingual transfer which the total result was 248 or $43.43 \%$ error. Thus, it can be concluded that the most frequent grammatical errors that happened among the subject was error of omission, while the most common source of errors was intralingual transfer.
\end{abstract}

Keyword: grammatical error, writing, recount text.

\begin{abstract}
Abstrak
Tata bahasa yang baik adalah salah satu komponen penting dalam penguasaan keterampilan menulis. Namun, kesalahan tata bahasa masih menjadi masalah penting dalam penulisan, terutama bagi pebelajar Bahasa Ingrgis sebagai Bahasa Asing. Penelitian ini bermaksud untuk mengetahui jenis-jenis kesalahan tata bahasa yang sering dilakukan siswa dan untuk mengetahui sumber utama kesalahan tata bahasa tersebut dalam penulisan recount text siswa. Penelitian ini dirancang sebagai penelitian kualitatif deskriptif. Teks recount yang dikerjakan oleh siswa kelas delapan SMP Pelangi Dharma Nusantara pada tahun akademik 2019/2020 dijadikan sebagai sumber data dalam penelitian ini. Data dianalisis berdasarkan teori kesalahan yang diajukan oleh Dulay (1982) tentang taksonomi strategi permukaan dan teori sumber kesalahan tata bahasa yang dikemukakan oleh Brown (2007: 263). Hasil analisis menunjukkan bahwa jenis kesalahan tata bahasa yang paling sering muncul adalah kelalaian yang total mencapai total 171 kesalahan atau sekitar $37.33 \%$ dari keseluruhan kesalahan yang ada. Sementara itu, sumber utama kesalahan tata bahasa adalah transfer intralingual yang total hasilnya 248 kesalahan atau sekitar $43,43 \%$ dari total kesalahan yang ada. Jadi, dapat disimpulkan bahwa kesalahan tata Bahasa yang paling sering muncul adalah kelalaian dan sumber
\end{abstract}


kesalahan yang paling banyak adalah karena adanya pengaruh dari transfer intralingual.

Kata Kunci: Gramatikal eror, Menulis, Teks Recount

\section{INTRODUCTION}

Writing is one of the language skills that need to be developed in studying English. It can be a medium for expressing a person's ideas, feelings, and opinions in written form, and the result can be meaningful for the writer himself and/or for other (Indrilla \& Ciptaningrum, 2018). However, writing is a complex skill. Other than the mastery of the components of texts required by the type of texts targeted, a good piece of writing also needs to be supported with extensive vocabulary and a good mastery of grammatical rules, for without proper sentence constructions, it would be difficult for readers to read and understand a piece of writing (Tarigan et al., 2019).

Grammar includes clear principles of formation and interpretation of words, phrases and sentences in order to create a meaningful row of sentences (Asni \& Susanti, 2018). With good formation of words, grammar makes the message of an individual's ideas delivered properly (Ardin, 2017). As written text is read in the absence of the writer, to make it easily understandable through good grammar is very important. However, grammatical errors still become an important problem in writing, especially for EFL students. Suwastini and Yukti (2017) for example were concerned with the errors committed by students learning English as Foreign Language in a vocational school in Bali and revealed that misformation and omission were the most common type of error committed in the students' short-biography writing that they result. Very similar result was found by Megantari and Budasi (2018) who observed the grammatical errors in vocational school students' narrative text, and revealed that misinformation and omission were committed most frequently by the students. Budiarta, Suputra and Widiasmara (2018) also conducted error analysis among junior high school's narrative texts and revealed that misformation and ommisions were also the types of errors that happened most often in the students' writing.

Concerning the source of grammatical errors committed by students in their writing text, studies by Suwastini and Yukti (2017); Budiarta, Suputra, and Widiasmara (2018) and study by Megantara and Budasi (2018) identified native language interference as the main source of students' grammatical errors. Budiarta, Suputra, and Widiasmara (2018) found that the difference between grammatical rules of target language languages and native language was the main cause for students' errors (Budiarta et al., 2018). Meanwhile, Suwastini and Yukti (2017) identified interlingual transfer as the dominant cause of of the students' grammatical errors among the students' short biography texts that they observed. In addition, the students often translate their ideas from native language to target language in composing writing ( Isa, Risdaneva and Alfayed (2017)). Related to these findings, Suwastini and Yukti (2017) suggested that to minimize students' grammatical errors, more concerned should be placed by teachers on the comparison between the students' native language and target language to highlight the differences in the language systems and grammatical rules between the two languages.

Thus, it is very important to identify the types of grammatical errors and the source of these grammatical errors in 
students' writing, in order to be able to decide strategies to overcome this problem and to prevent grammatical errors to become fossilized further, while supporting the students' writing skills. Therefore, the present study focused itself on the identification of the students' grammatical errors committed by a junior high school in Bali, in order to be able to identify the possible sources of that error and to design potential strategies to overcome these errors. The present study employed survey strategy taxonomy from Dulay et al. (1982:154), which focuses on the structural changes made by the learners. They may have to eliminate items and add ones that are not important not in accordance with the form of a sentence. They may misform and misorder the items. Survey strategy taxonomy is divided into four categories. First, omission error is when the learner omits the item that is a mandatory part in the sentence to form a correct sentence. In omission, there two types of morphemes in a sentence, such as grammar morphemes and content morphemes. In grammar, morphemes include preposition, article, to be, conjunction, and marker. Second, addition error is when the learners put an item that ought not to arise in a sentence. Furthermore, it has three types, namely double marking, regularization, and simple addition. Third, misformation errors related to the implementation of incorrect form of items in right place where correct form should be added in the sentence. The learners choose incorrect forms of phoneme, morpheme, structure, or vocabulary. Misformation has three types, namely regularization, archi form, and alternating form. Fourth, misordering error is error in placing morpheme in the wrong order in an utterance.

To analyze the possible source of errors committed by the students' the present study employed Brown's (2007:
263) categorizations of grammatical errors, where he categorized grammatical erros into four groups. First, interlingual transfer is the negative interference of the native tongue. It is due to the learners use the linguistic form of their first language in making target language sentences. Second source of error is intralingual transfer. It occurs when the learners have not mastered the target language, they are overgeneralization the rules or incomplete application of rules. Third, context of learning is related to the error come from the outside of learners. For instance, teacher and material. They may lead the learners to hypothesize the language incorrectly. The teacher misleads in explaining the concept or the material in the book is difficult to understand. Thus, the learners hypothesize the language incorrectly then the error is made. Fourth source is communication strategy that is influenced by students' learning styles. They make their strategy to learn the target language and deliver it with their style although they have not mastered yet the needed competence of the target language. Hence, it leads to an error.

Based on an interview with an English teacher of SMP Pelangi Dharma Nusantara, it was found that grammatical errors was frequently committed by the eighth grade students when writing, especially recount text. It is a text that retells sequent of a past event in order to inform or entertain the reader (Husna \& Multazim, 2019). It tells the person who involved, what he/she experienced, where and when it occurred. Based on the result of previous study conducted by Isa, Risdaneva and Alfayed (2017), verb tense and word choice were the two main types of grammatical errors in writing recount texts committed by the students. Similar results were found by the studies conducted by Ardin (2017), Ilmiah (2016), Yudari (2017), Fridayanthi (2017) Asni and Susanti (2018), Husna 
and Multazim (2019), and Tarigan, et al. (2019).

Thus, the present study was focused on investigating the types and sources of grammatical erros in the students' recount text. The research questions of the present study can be stated as follow. What are the major type of grammatical error committed by the eighth students at SMP Pelangi Dharma Nusantara in writing recount text?, What are the major sources of the grammatical errors committed by the eighth students at SMP Pelangi Dharma Nusantara in writing recount text?

Based on the problems stated above, this research aimed at identifying and analyzing the major types of grammatical errors and the major source of grammatical errors in writing recount text committed by the eighth students of SMP Pelangi Dharma Nusantara

\section{METHODS}

The present study is a qualitative descriptive research. The followings are Research methods consist of four parts, as explained below.

\section{Data Source}

The source of data was the writing of the eighth-grade students of SMP Pelangi Dharma Nusantara in academic year $2019 / 2020$. To be more specific, the writing was focused on the students' recount texts only. All eighth-grade students of SMP Pelangi Dharma Nusantara which consisted of 2 classes (A and B) as a population in this study. Class B which consisted of 30 students were chosen as the sample of the study by using purposive technique sampling. It was chosen due to that class had the lowest mean score in writing recount text, thus it was deemed important to focus on the grammatical errors of these students' recount text. The theme was "Best experiences in life". All the recount text investigated in this study were authentically written by the students.

\section{Data Collection}

Data were collected through the observation of the students' recount texts. The theme of the recount text was "Best experiences in life," which were written by the students in a 40 minutes practice after the lesson about recount text was over. The observation was conducted to identify the errors that occurred in the students' recount text. Following the types of errors proposed by Dulay et al., (1982), the present study employed observation checklist to facilitate the recording of the data identified during the observation.

\section{Data Analysis}

After the data were collected, the next step was data analysis, which were divided into two steps. The first steps was the types of students' grammatical errors using the surface strategy taxonomy theory proposed by Dulay et al., (1982: 154), in which they argues that there are four main types of errors, namely: omission, addition, misformation and misordering. After the types of errors were identified and classified into each of the groups proposed by Dulay et al. (1982), the analysis was continued to the identification of the source of each errors, following the categorization of source of grammatical errors proposed by Brown (2007), in which he argues that grammatical errors can happen because of four sources, namely: interlingual transfer, intralingual transfer, context of learning, and communication strategy.

\section{RESULT AND DISCUSSION}

\section{Types of Grammatical Error}

This study was aimed at identifying and analysing the major types of grammatical errors committed by the eighth students, as well as analysing the 
the source of those grammatical errors. To find out the types of grammatical errors, the students' recount texts were observed and analysed using theory of surface strategy taxonomy by Dulay et. al (1982:154). Table 1 below displays the errors that occurred in the students' recount text writing.

Table 1. Recapitulation the Types of Error

\begin{tabular}{cccc}
\hline No Types of Error & $\begin{array}{c}\text { Frequ } \\
\text { ency }\end{array}$ & Percentage \\
\hline 1 & Omission & 171 & $37.33 \%$ \\
2 & Addition & 72 & $15.72 \%$ \\
3 & Misformation & 169 & $36.90 \%$ \\
4 & Misordering & 46 & $10.04 \%$ \\
\hline
\end{tabular}

Table 1 shows that the description of types error of students' writing. They committed omission, addition, misformation, and misordering errors.

Omission errors appeared 171 times or $37.33 \%$ of the total errors. The following are examples of omission errors committed by the students. First, they missed the suffix "-ed". For example, "my mother and I cook together. Because the activity expressed was a past experience, the verb "cook" should be in its past form " "cooked". Second, the deletion of "to be" in the sentence. For instance, "when $I$ in elementary school, ...". The subject " $P$ " was supposed to be followed by "was" as a verb auxiliary to form the basic Subject-Predicate construction of the sentence. The third omission was the missing "-s" as plural maker. For instance, "I got many novel". The word "novel" should be changed into "novels". The fourth omission error was the deletion of article as singular marker. For example, "she had new bicycle". It should be written as, "she had a new bicycle". As the examples above, students erase grammatical morphemes in composing a sentence.

The second type grammatical error was addition error which the total error was 72 or $15.72 \%$. It usually happened because the students put an item that ought not to appear in a sentence. For instance, "I did not believed with the announcement". The students added past auxiliary and past verb in the same sentence, which was grammatical redundancy. The past verb "believed" should be changed into "believe" because the sentence was a negative sentence with a past auxiliary "did" to proceed the negative marker "not". The students also made double subjects in a single sentence. For instance, "My parents they hugged me tight". It should be "My parents hugged me tight," or "My parents, they hugged me tight." These inappropriate item additions in students' sentence were typical of the students' addition errors.

The third type of grammatical errors committed by the students was misformation error. There were 169 misformation errors committed or $36.90 \%$ of the total errors. In these errors, the students applied morphemes or structures that were not grammatically appropriate. There were two kinds of misformation error committed in the students' recount texts, namely alternating form and regularization error. An example of alternating form was, "I maked cake by myself". The word "maked" was incorrect incorrect past form of the verb "make". Because it was an irregular verb, it should be written "made". An example regularization error was "I saw many beautiful gooses in the zoo." The word "gooses" should be changed into "geese". The students made a regularization error since they placed a regular marker for pluralization in the context of irregular noun.

The last type of error committed in the students' recount text was 
misordering, with 46 errors or a $10.04 \%$ of the total errors. Misordering errors usually occur when students committed an error in morpheme placement within a sentence. An example of the students' misordering error was, "I was happy very". The sentence should be "I was very happy". The students made an error by incorrect placement of morphemes in the sentence, where the adverb "very" should have been placed before the adjective "happy" rather than before it.

According to the findings above, the most frequent type of grammatical errors committed by the students was omission error with 171 errors or $37.33 \%$ out of the total errors. The next most frequent type of errors committed was misformation error, with 169 errors or $36.90 \%$ of the total errors. Errors of addition and misordering came third and forth with a total of 72 errors and 46 errors respectively, or $15.72 \%$ and $10.04 \%$ of the total errrors.

The findings of this study were slightly different from the study that was conducted by Yudari (2017). She found that misformation error as the most frequently occurred. Meanwhile, this study found that omission error with was the most frequently occurred in the students' recount text writings. It was similar to the study that was conducted by Asni and Susanti (2017) who found that omission error as the most frequently occurred. Then, this study found that misformation was the secondly type of the students' errors. It was in line with the research result by Fridayanthi (2017) who found that misformation errors was the secondly types of errorrs committed by the students. Furthermore, addition and misordering errors were as the third and fourth types of the students' errors. It was consistent with the study that was conducted by Tarigan, et al. (2019).

\section{Source of Grammatical Error}

Following the classification of the source of grammatical errors theory proposed by Brown (2007), the present study observed the four sources proposed by Brown (2007) to have become possible cuases of the students' errors in their recount text, namely interlingual transfer, intralingual transfer, context of learning, communication strategy. Table 2 below displays the frequency of the occurrence of the sources identified from the students' errors.

Table 2. Recapitulation Source of Grammatical Error

\begin{tabular}{cccc}
\hline No & $\begin{array}{c}\text { Source of } \\
\text { Error }\end{array}$ & $\begin{array}{c}\text { Freque } \\
\text { ncy }\end{array}$ & Percentage \\
\hline 1 & $\begin{array}{c}\text { Interlingual } \\
\text { Transfer }\end{array}$ & 223 & $39.05 \%$ \\
2 & $\begin{array}{c}\text { Intralingual } \\
\text { Transfer }\end{array}$ & 248 & $43.43 \%$ \\
3 & $\begin{array}{c}\text { Context of } \\
\text { Learning }\end{array}$ & 33 & $5.78 \%$ \\
& $\begin{array}{c}\text { Communi } \\
\text { cation } \\
\text { strategy }\end{array}$ & 67 & $11.73 \%$ \\
\hline
\end{tabular}

As can be observed in the Table 2 above, all of the four sources of grammatical errors proposed by Brown (2007) had been identified as the possible causes of the grammatical errors found in the students' recount texts. The first source is from interlingual transfer. It was source of error made by student with the total result of 223 or $39.05 \%$ of the total errors. It occurred when the students' first language influenced target language. The students wrote " $M y$ mother gave me cake birthday". The correct sentence should be "My mother gave me birthday cake." From that sentence, it can be observed that the students used their first language pattern, 
that is Indonesian language, to form English sentence. Another example was "Last year, I bought many firework". The noun "firework" should be added with plural marker "s" to form "fireworks." In this example, the students didn't put suffix " $s$ " as plural maker. This error happened because their first language did not have suffix "s" as a plural marker, thus the students had not applied to the plural countable noun to the stem "firework" to make it plural. It means those errors occurred due to influence of the students' first language system on their target language production.

The second source of grammatical error identified in this study was intralingual transfer. It was the cause that affected the students' grammatical errors most frequently, as it was identified as the source of 248 errors or $43.43 \%$ of the total errors. It happened when the students have not mastered the target language, overgeneralization one of the target language rules to other sentence constructions, and incomplete application of the rules of the target language. For instance, "2 years ago, I come to uncle house to celebrate Ramadan Day". In this sentence, the students used the verb "come" not "came". This kind of error happened because the students failed to recognized the English tenses and how they affect the verb form. In this case, the student failed to recognize that the statement was to express past experience and thus past tenses should applied, where the verb should be in its past form, hence "come" should be "came." Another example was "My family and I were enjoyed the panorama". In this case, that sentence implies the student generalized to be "were" for past tense verb while they had put "enjoyed" as verb for past tense.

The third source of grammatical errors in the students' recount texts was the context learning. It was the lowest source of error made by the student, with the total result 33 or $5.78 \%$ of the total errors. This kind of source of errors affected the students due to the teacher's explanation, incorrect description of a textbook or a non-contextualized memorized pattern. It can be seen in this sentence. "Sanur beach was my favorite place was reminded me all of my best memories." The sentence should be formed in complex sentence with subjective clause, "Sanur beach was my favorite place, which reminded me of my best memories". In this case, the students did not use the relative pronoun to connect word in the sentence. It can occur due to the teacher's explanation which did not have wide coverage. Thus, the student wrote inappropriate sentence.

The fourth source of grammatical errors identified among the students' recount text was communication strategy, with the total result of 67 errors, or $11.73 \%$ of the total errors. It is related to students learning when learning second language. For example, "I won football competition. They was the best experience". From that sentence, the student had incorrect word choice. The word "They" for the pronoun of my "football competition" should be replaced by "It". The students tried to communicate their view about relative pronoun but unfortunately the strategy leads them to the error.

According to the research findings, the major source of grammatical errors committed by the students was intralingual transfer, with 248 errors or $43.43 \%$ of the total errors. The next most frequent source of errors was interlingual transfer, with 223 errors or $39.05 \%$ of the total errors. The third and fourth most frequent sources or errors were communication strategy and context of learning with 67 errors and 33 errors respectively or $11.73 \%$ and $5.78 \%$ of the total errors.

Furthermore, this finding study was different from the study that was 
conducted by Sermsook, Liamnimitr Pochakorn (2017), who found that interlingual errors or first language interference was found to be the most source of error. On the other hand, this study found that intralingual transfer was the most sources of the students' errors. It was supported by Isa, Risdaneva and Alfayed (2017); Tarigan, et al. (2019) who found the intralingual error was found to be the major source of errors. In addition, this study found that the secondly source of errors was interlingual transfer. It also had a similar finding with Asni and Susanti (2017) who found that interlingual transfer errors as the second source of errors. Moreover, the third place of source of errors in this study was communication strategy. Otherwise, it was different from the study that was conducted by Yudari (2017) who found that communication strategy error was the least source of the errors. Furthermore, the least source of the error in this study was context of learning. It has similar to the finding from Fridayanthi (2017) who found that context of learning was the least source of the error.

\section{CONCLUSION}

Based on the results and discussions above, there are two points that can be deduced in regards to the problems of this research. First, there were four types of grammatical error committed by the eighth students of SMP Pelangi Dharma Nusantara in writing recount text based on theory by Dulay et al. (1982: 154). They were omission, addition, misformation, misordering errors. The major type of grammatical errors was omission which the total result was 171 or $37.33 \%$. Meanwhile, the lowest type of grammatical errors was misordering which the error was 46 or $10.04 \%$.

Second, there were four sources of grammatical error made by students based on the theory proposed by
Brown (2007: 263). They were interlingual transfer, intralingual transfer, context of learning and communication strategy. The major source of grammatical errors was intralingual transfer which the total result was 248 or $43.43 \%$ error. Whereas, the lowest was 33 or $5.78 \%$. In short, the students do not have a deep understanding in using English grammar in composing recount text.

Hence, the English teacher has to be more concerned on students' grammar so that the students could minimize grammatical errors in their writing. As the scope of this research was limited in junior high school students, it is recommended that further research to collected the data in higher educational institutions so the result could be generalized.

\section{REFERENCES}

Ardin, H. (2017). Analyzing Errors In Recount Text Written By The Third Year Students Of SMAN 1 Pinrang. JIKAP PGSD: Jurnal Ilmiah Ilmu Kependidikan, 1(1), 1. https://doi.org/10.26858/jkp.v1i1.5 040

Asni, S. L., \& Susanti, S. (2018). An Analysis of Grammatical Errors in Writing Recount Text at the Eighth Grade of SMP Negeri 20 Kota Jambi. International Journal of Language Teaching and Education, 2(2), 131-144. https://doi.org/10.22437/ijolte.v2i2. 5205

Brown, H. D. (2007). Principle of Language Learning and Teaching (5th Editio). Pearson Education, Inc.

Budiarta, L. G. R., Suputra, P. E. D., \& Widiasmara, I. K. (2018). An 
analysis of grammatical errors on narrative writing committed by the ninth grade students of junior high school. International Journal of Language and Literature, 2(3), 98107.

https://doi.org/10.23887/ij1l.v2i3.16 315

Dulay, H., Burt, M., \& Krashen, S. (1982). Language Two. Oxford University https://doi.org/10.2307/327086

Husna, A., \& Multazim, A. (2019). Students' difficulties in writing recount text at inclusion classes. LET: Linguistics, Literature and English Teaching Journal, 9(1), 52-76.

https://doi.org/10.18592/let.v9i1.30 77

Ilmiah. (2016). An analysis of gramatical error in writing recount text. English and Literature Journal, 3(1), 9-21. http://journal.uinalauddin.ac.id/index.php/elite/articl e/view/3390/3197

Indrilla, N., \& Ciptaningrum, D. S. (2018). An approach in teaching writing skills: Does it offer a new insight in enhancing students' writing ability. Journal: A Journal on Language and Language Teaching, 21(2), 124-133. https://doi.org/10.24071/1lt.2018.21 0201

M. Isa, Q. N., Risdaneva, R., \& Alfayed, A. (2017). An analysis of acehnese EFL students' grammatical errors in writing recount texts. Englisia Journal, 5(1), 41-50. https://doi.org/10.22373/ej.v5i1.23 01
Megantari, N. W. ., \& Budasi, I. G. (2018). The error analysis reflected in English recount writing. Lingua Scientia, 25(1), 37-52. https://doi.org/10.23887/ls.v25i1.18 822

Sermsook, K., Liamnimitr, J., \& Pochakorn, R. (2017). An analysis of errors in written English sentences: A case study of thai EFL student. English Language Teaching, 10(3), 101-110. https://doi.org/10.5539/elt.v10n3p1 01

Suwastini, N. K. ., \& Yukti, W. G. S. (2017). Errors analysis in short biography text written by the 11th grade students of a vocational high school in Singaraja. International Journal of Language and Literature, 1(1), 1-10. https://doi.org/10.23887/ijll.v1i1.96 12

Tarigan, N. W. P., Siregar, Y. S. P., Mawarni, C. I., Simanjuntak, C. W. B., \& Tanjaya, A. (2019). Grammatical errors on students' writing of recount text. Linguistic, English Education and Art (LEEA) Journal, 3(1), 189-200. https://doi.org/10.31539/leea.v3i1.9 95 